\title{
PROTEAN CAREER ORIENTATION AND CAREER PLANNING AMONG EMPLOYEES IN HIGHER EDUCATION INSTITUTIONS IN JAFFNA DISTRICT
}

\author{
Shanthakumary Mahenthiran Aloysius $^{\mathrm{a}}{ }^{\square}$, T. Velnampy \\ ${ }^{a}$ Department of Human Resource Management, \\ University of Jaffna, Sri Lanka \\ ${ }^{b}$ Dean, Faculty of Management studies \& Commerce, \\ University of Jaffna, Sri Lanka
}

\begin{abstract}
Protean career orientation is the individual mindset that has only fifty years of history. People have been changing slowly but steadily their career related moves to meet their career aspirations and the priorities that they have. Sri Lankan employees are in the same line in facing the changes take place in the career world. Employees develop many strategies to meet the challenges. They set career goals clearly. The present study aims to examine the effect of protean career orientation on career planning of individuals. 154 staff from public Higher Education Institutions (HEIs) participated in the study. A self-administrated questionnaire issued among the respondents. The study found that protean career orientation has significant direct impact on career planning, there is no statistically significant mean difference between men, and women in terms of their career orientation however, they are significantly different in planning their careers.
\end{abstract}

Keywords: protean career orientation, career goal setting, gender, higher education institutions

\section{Introduction}

Career orientation of the individual is reflective to the vicissitudes take place in macro environment of the industries who are supportive to the peoples by providing means in return to rented services to continue their life. Due to the growing transactional mindset, people and the organizations always look for the best to fulfill their values and needs. According to the literature on career, people seek opportunity to fulfill their career aspirations and cross the boundaries of the organization or nation. Due to the attributes of the generations, employees exhibit certain work-related behavior. Generally, it is noted, that the generations $\mathrm{X}$ and $\mathrm{Y}$ are native to technology, give priority to family and like more autonomy at work. These two generations are majority in the work places as the rest of baby boomers are almost at latter part of their career stage. Therefore, they give importance to their values in selecting their jobs and organizations.
Employees in the all over the world, have many similarities in terms of their career dispositions. The important point is noted here, the nature of the career world including nature of work and its environment, family related priorities, values and growth of the private sector in Western countries or the countries that have similar culture cannot be comparable to the developing world in Asia. However, the macro environment of the industries are almost similar due to the effect of globalization. It is observed that the employees in Sri Lankan organizations have mixed attributes in relation to the psychological contract, even though there are visible changes in the employees and organization selection processes and the underlying criteria. Employees expect care from the organization and depending on organizational support for their career development activities. Dissanayake (2011, 2012) pointed out that career orientation of Sri Lankan employees has been changing and employees give importance to their 
priorities, it is the case to the public sector organizations too (Shanthakumary, 2019a \& 2019b). Especially, it was found that people prefer more autonomy in decision-making and give importance to their work and life related values. Employees in Sri Lankan organizations show a steady move toward their career destination, as they are rich in information regarding their present and future jobs. It is considered here that the above said attributes are common among new careerists. Especially, protean careerist prefer more autonomy at their job and believe they are determiners their own career destiny. Another important feature is they prefer subjective career success rather than objective. As noted in Shanthakumary(2019a \& 2019b), even though people who work in the public sector perceive limited organizational support for their career development, they strive to achieve their career ambitions due to the effect of protean career orientation.

\section{Research Question}

Generally cultural, economic and gender related factors affect career development or career decision making and the adjustment of the people (Byars \& Hackett, 1998). People who have strong protean career orientation prefer more freedom in decision-making and tend to plan their careers i.e. they anticipate future changes and proactively take initiatives to achieve career goals (De Vos \& Soens, 2008 \& DiRenzo, 2010). Since, the employees in the public sector organizations in Sri Lanka are not exceptional in their career orientation as the majority of them shift to protean career orientation. Job market of public sector is different from private sector due to the influence of various pressures and agenda. Since, the public sector hire employees from open and limited examinations, it deviates in the appointment of graduates or employees HEIs. On the other hand, researchers pay less attention on career planning of the public sector employees. Employees in the public sector prefer to continue the present position even they are not promising future growth for various reasons such as social security system, privilege given to the public sector employees and risk of getting new job.
According to the previous studies career planning may support the employees to experience career success, employability and work life balance (DiRenzo, 2010; DiRenzo, Greenhaus \& Weer,2017). There are less number of studies carried out by Sri Lankan researcher on protean career orientation (Shanthakumary, 2015; Kailasapathy \& Nishanthy, 2020) and its outcomes and no web source available in connecting protean career orientation and career planning of the employees. Therefore, the present study will support to increase the present stock of literature.

Does protean career orientation effect on career planning of the employees in HEIs?

\section{Objectives of the study}

The following objectives set out for the study To examine the impact of protean career orientation on career planning

To analyze the gender differences in terms of the test variables

\section{Literature Review and Hypothesis Development}

This section deals with previous studies on protean career orientation and career planning.

\section{Protean career orientation and Career planning}

Career is an integral part of human life in modern society. The ultimate aim of education is to receive best career opportunity/s. Hall (2002) says career is considered a lifelong sequence of job-related experiences of the individual. This experience and activities are directed at personal and organizational goals through which a person passes during his or her lifetime that is partly under their own control and partly under others' control. This experience and activities are directed at personal and organizational goals through which a person passes during his or her life time that is partly under their own control and partly under others' control. Similar explanations have been given by many scholars like Weinert (2001); Greenhaus, Callanan \& Godshalk (2010). 
Career is defined as experience or learning or knowledge or skill or their combination earned by the individual from his or her sequence of jobs through liner progression or due to lateral mobility or boundaryless career move and (from other organization), it could be related or unrelated to the position held by a person (Shanthakumary,2019).

Protean career orientation is one of the new career orientations of the careerists and it was firstly introduced by D.T. Hall (1976) in his book on 'careers in organizations'. The term 'protean' derived from Greek word 'proteus' which is the name of the sea god who is able to change his shape at his will. According to Hall (2004) person is the in charge for his/ her career not the organization. Career decision-making behind the protean careerists reflect two different predispositions such as self- directedness and value driven. Self-directedness means the degree to which people accept responsibility for their career decision and action whereas value driven means one's internal value give guidance to individual to take career related decisions (Briscoe et al., 2006) and both of the aspects lead to psychological career success.

Hall (2004; 2018) identified two major competencies of protean careerists: adaptability and identity and further he stated that higher the protean career orientation and higher level of adaptability lead to proactive behavior. Researchers like De Vos and Sones (2008); DiRenzo (2010); DiRenzo, Greenhaus \& Weer (2017) considered career planning as the components of proactive career management behaviors and they found positive association between protean career orientation and career planning.

Rahim (2015) found that components of protean career orientation have positive impact on career goal development. Likewise, Herrmann, Hirschi \& Baruch (2015) also found significant positive association between protean career orientation and career planning.

Shanthakumary (2019) found that protean career orientation has significant impact on career planning of graduate employees. Her study further revealed that they are comparable in planning their careers. Moreover, they are similar in self-directed and value driven career orientations as well.

\section{Hypothesis}

Based on the literature survey the following hypothesis were formulated

$\mathrm{H}_{1}$ : Protean career orientation has direct impact on career planning of the employees. $\mathrm{H}_{2}$ : Male and female employees are different in terms of their career orientation and career planning

\section{Methodology}

\section{Instruments and Sample}

A self-administrated five-point Likert scale questionnaire was issued among the respondents to collect the required data which consists of statements in relation to demographical profile, protean career orientation and career planning. 14 statements were given to measure selfdirected career orientation (SD) and 8 statements given for value driven career orientation(VD) and the statements developed by the Briscoe et al 2006, Gubler, 2011 and the researcher. The scale for career planning (CP) was developed by Gould (1979) and the researcher. The response ranges from strongly agree to strongly disagree. Conveniently, selected 154 academics in HEIs gave their responses. It was identified that the total mid and early career employees in HEIs is 1001. It was planned to cover $20 \%$ of the population. Therefore, 200 questionnaires issued among them and 159 responses were able to collect back. Among the questionnaires issued 154 responses found as usable.

\section{Analytical Survey and Statistical Methods}

The collected data were analyzed using SPSS version 21 and SMART PLS, version 3 which is suitable to perform Structural Equation Modelling for small sample size. First, All the 22 items for PCO were loaded together to perform the exploratory factor analysis. Seven items were removed, as the values were less than the criterion value of 
0.5 (Hair et al,204). The analysis suggested two group of items, they named as suggested in the literature as SD and VD. The results confirmed that the finding of Briscoe et al (2006).

Eight Items of $\mathrm{CP}$ loaded to perform exploratory factor analysis and the results revealed that the value of three items were less than 0.5, which was the cutoff value for retaining any item in the data set. They also were excluded for further analysis and the varimax rotation suggested one group. Therefore, rest of the items were retained to test the measurement model. The following table clearly explains the impact of protean career orientation (PCO) on career planning (CP).

\section{Results and Discussions}

It is necessary to examine the reliability and the validity of the data set to confirm whether the data set is qualified for decision making or. The following table exhibits the major components of the reliability and the validity analysis and their values.

Table 1 Construct Reliability and Validity

\begin{tabular}{|l|c|l|l|l|}
\hline & Cronbach's Alpha & rho_A & CR & AVE \\
\hline CP & 0.939 & 0.963 & 0.955 & 0.811 \\
\hline PCO & 0.935 & 0.944 & 0.943 & 0.526 \\
\hline
\end{tabular}

Source: Survey data

The table given above depicts the model has sufficient reliability and validity. According to Hair et al (2014), value of Cronbach's Alpha should be greater than 0.6 which means the measure has internal consistency, however, composite reliability $(\mathrm{CR}>0.6)$ and average variance extracted $(\mathrm{AVE}>0.5)$ are above the criterion values. Both of the variables have satisfactory composite reliability and average variance extracted. According to the above table, the measure has discriminant validity as the inner value is lower than the diagonal.

Table 2: Discriminant Validity

\begin{tabular}{|l|l|l|}
\hline & CP & PCO \\
\hline CP & $\mathbf{0 . 9 0 0}$ & \\
\hline PCO & 0.481 & $\mathbf{0 . 7 2 5}$ \\
\hline
\end{tabular}

\section{Hypothesis Testing}

The measurement model shown in Figure 1 explains to what extent PCO impacts on CP. The measurement model shows that PCO has significant direct impact on $\mathrm{CP}$ of individuals. The path coefficient value is $0.481, \mathrm{p}<0.01$ and the $\mathrm{r}^{2}=0.232$ shows $23 \%$ of variation in career planning is explained by protean career orientation. However, Bootstrapping was performed to examine the significance of the path. $\mathbf{5 0 0 0}$ sample was set generate the results 


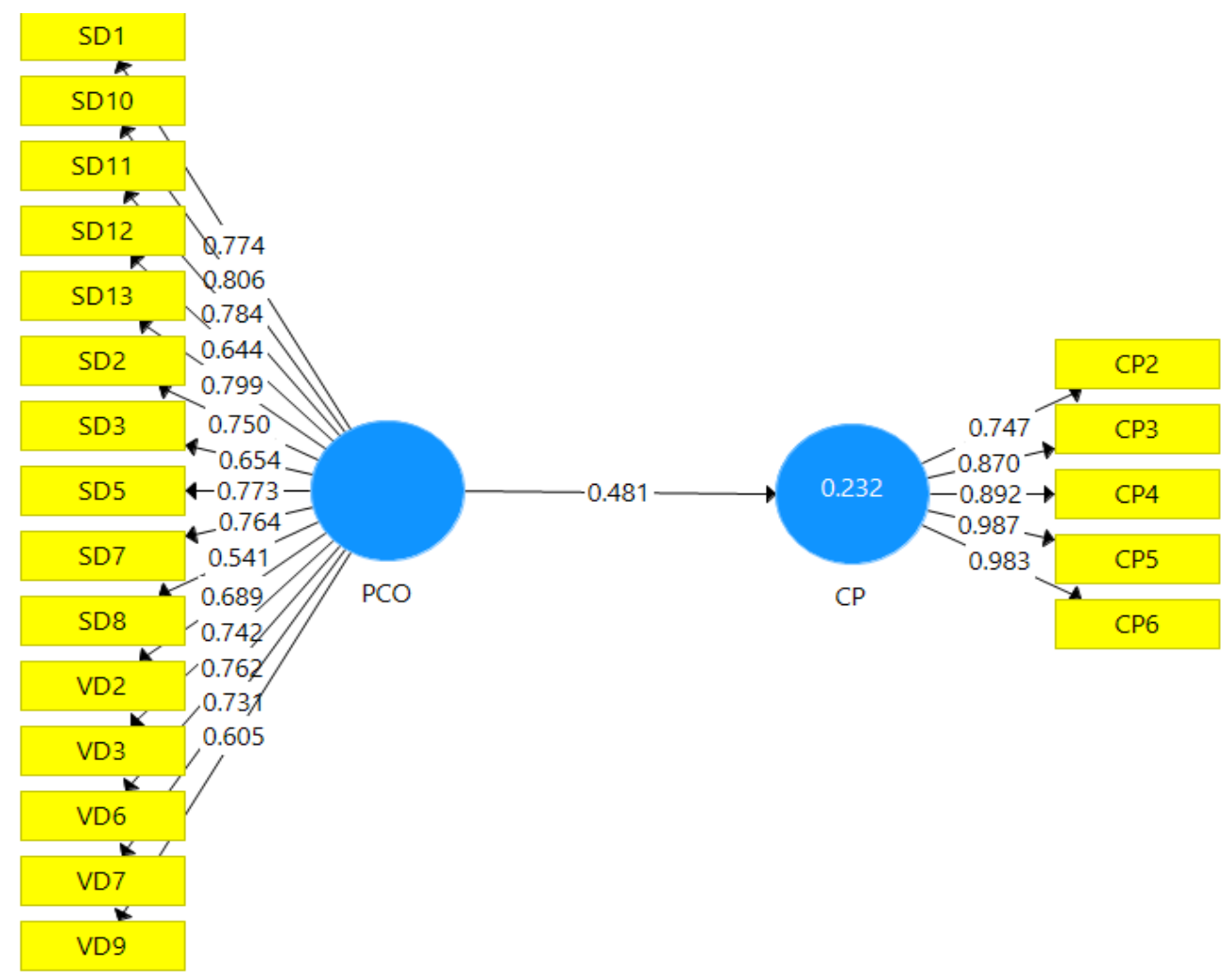

Figure 1: The Measurement Model

Table 3: Results of Bootstrapping

\begin{tabular}{|l|l|l|l|l|l|l|l|l|}
\hline Path & $(\mathrm{O})$ & $(\mathrm{M})$ & STDEV & T Statis & $\begin{array}{l}\mathrm{P} \\
\text { Values }\end{array}$ & Bias & $2.5 \%$ & $97.5 \%$ \\
\hline PCO -> CP & 0.481 & 0.492 & 0.070 & 6.920 & 0.000 & 0.010 & 0.336 & 0.605 \\
\hline
\end{tabular}

$O$ - Original Sample M- Sample Mean STDEV-Standard Deviation

The following table is used to test the second hypotheses which assume that the gender groups are different in terms of their PCO and $\mathrm{CP}$.

Table 4: Levene's Test for Equality of Variances

\begin{tabular}{|c|c|c|c|c|c|c|c|c|c|}
\hline \multicolumn{10}{|c|}{ Independent Samples Test } \\
\hline & & & \multicolumn{7}{|c|}{ t-test for Equality of Means } \\
\hline & \multirow[t]{2}{*}{$\mathbf{F}$} & \multirow[t]{2}{*}{ Sig. } & \multirow[t]{2}{*}{$\mathbf{t}$} & \multirow[t]{2}{*}{ df } & \multirow[t]{2}{*}{$\begin{array}{c}\text { Sig. } \\
(2- \\
\text { tailed })\end{array}$} & \multirow[t]{2}{*}{$\begin{array}{c}\text { Mean } \\
\text { Difference }\end{array}$} & \multirow[t]{2}{*}{$\begin{array}{c}\text { Std. } \\
\text { Error } \\
\text { Difference }\end{array}$} & \multicolumn{2}{|c|}{$\begin{array}{c}95 \% \\
\text { Confidence } \\
\text { Interval of the } \\
\text { Difference } \\
\end{array}$} \\
\hline & & & & & & & & Lower & Upper \\
\hline $\begin{array}{l}\text { Equal } \\
\text { variances } \\
\text { assumed }\end{array}$ & 4.486 & .036 & 2.016 & 152 & .046 & .1866 & .09255 & .00373 & .36945 \\
\hline $\begin{array}{ll}\text { PCO } & \text { Equal } \\
& \text { variances } \\
\text { not } \\
\text { assumed }\end{array}$ & & & 2.003 & 139.49 & .047 & .1866 & .09316 & .00241 & .37078 \\
\hline
\end{tabular}




\begin{tabular}{|l|l|l|l|l|l|l|l|l|l|} 
& $\begin{array}{l}\text { Equal } \\
\text { variances } \\
\text { assumed }\end{array}$ \\
$\mathrm{CP}$ & 4.031 & .046 & 3.045 & 152 & .003 & .3702 & .12159 & .12996 & .61042 \\
$\begin{array}{l}\text { Equal } \\
\text { variances } \\
\text { not } \\
\text { assumed }\end{array}$ & & & 3.021 & 135.19 & .003 & .3702 & .12256 & .12781 & .61257 \\
\hline
\end{tabular}

Independent sample $\mathrm{T}$ test was performed to find out mean differences between the gender of the respondents in relation to $\mathrm{PCO}$ and $\mathrm{CP}$. As per the given table $4, \mathrm{~F}$ and $\mathrm{T}$ statistics are significant as the probability values are less than 0.05 , however, the decision was confirmed via Man -Whitney $U$ test.

Table 5 Mann-Whitney U Test

Hypothesis Test Summary

\begin{tabular}{|c|c|c|c|c|}
\hline & Null Hypothesis & Test & Sig. & Decision \\
\hline 1 & $\begin{array}{l}\text { The distribution of avePCDnew is } \\
\text { the same across categories of } \\
\text { Gender. }\end{array}$ & $\begin{array}{l}\text { Independent- } \\
\text { Samples } \\
\text { Mann- } \\
\text { Whitney U } \\
\text { Test }\end{array}$ & .078 & $\begin{array}{l}\text { Retain the } \\
\text { null } \\
\text { hypothesis. }\end{array}$ \\
\hline 2 & $\begin{array}{l}\text { The distribution of avecp is the } \\
\text { same across categories of Gender. }\end{array}$ & $\begin{array}{l}\text { Independent- } \\
\text { Samples } \\
\text { Mann- } \\
\text { Wolhitney U } \\
\text { Test }\end{array}$ & .011 & $\begin{array}{l}\text { Reject the } \\
\text { null } \\
\text { hypothesis. }\end{array}$ \\
\hline
\end{tabular}

Asymptotic significances are displayed. The significance level is .05 .

According to the above test, the null hypothesis of equality of variance is accepted for PCO and it is rejected for CP. Therefore, it is concluded that men and women are equal in terms of protean career orientation and men and women are different in career planning. Mean value of the men (4.31) is greater than the women (3.94). Men have greater tendency to plan their career than women do.

\section{Conclusions}

The study identified that PCO has direct impact on career planning . PCO is the same between the gender groups whereas $\mathrm{CP}$ differs between the gender of the respondents - There are national and regional culture related factors play an important role in determining the value of the mean of CP. Sri Lankan women have to perform their domestic duties along with the career development activities. However, male dominated work and home environment and their own values as family is the first, they majority of them are unable to be proactive in managing their careers.

\section{References}

Briscoe, J.P., \& Hall, D.T., \& Frautschy DeMuth, R.L. (2006). Protean and boundaryless careers: an empirical exploration. Journal of Vocational Behavior, 69(1): 30-47. doi: 10.1016/j.jvb.2005.09.003.

Byars, A. M. \& Hackett,G. (1998). Applications of social cognitive theory to the career development of women of color, Applied and Preventive Psychology, 7(4),255-267.

De Vos, A., \& Soens, N. (2008). The Relationship Between Protean Career Attitude and Career Success: The Mediating Role of Career SelfManagement. Vlerick Leuven Gent Working Paper Series, 2008/10. 
DiRenzo, M.S. (2010). The role of protean career orientation and career capital on work and life outcomes, $\mathrm{PhD}$ thesis

DiRenzo, M.S., Greenhaus, J.H., \& Weer, C.H. (2015). Relationship between protean career orientation and worklife balance: A resource perspective. Journal of Organizational Behavior, 36(4): 538-560.

Dissanayake, E.L.K., \& Benfratello, L. (2010/2011). Determinants of Unemployment among Sri Lankan University Graduates an Econometric Analysis, Dissertation.

Dissanayake, E.L.K. (2012). Nonconventional model of career: Implication for Human Resource strategy for post war Sri Lankan Organizations. V.R.F Series, 472.

Hall, D.T. (1976). Careers in organizations. Glenview, IL: Scott Foresman.

Herrmann, A., Hirschi, A., \& Baruch, Y. (2015). The protean career orientation as predictor of career outcomes: Evaluation of incremental validity and mediation effects. Journal of Vocational Behavior, 88: 205-214.

Gubler, M. (2011). Protean and Boundaryless career orientations an empirical study of IT professionals in Europe. PhD Thesis, Loughborough University.

Hair, J.R., Anderson, R.E., Tatham, R.L., \& Black, W.C. (2014). Multivariate Data Analysis (7th ed.). Pearson Education Limited, USA.

Nishanthy, HM \& Kailasapathy,P 2016, 'Impact of protean career orientation on employee commitment', Proceedings of 40th IASTEM International Conference, Kuala Lumpur, Malaysia.

Rahim, N.B.B. (2015). Protean career orientation and individual well-being among professional engineers in Malaysia: mediating role of proactive career management behaviours, $\mathrm{PhD}$ Thesis.
Shanthakumary, MCMA 2015, 'Protean career orientation and career success among early career employees' Proceeding of ICCM, Faculty of Management Studies \& Commerce, University of Jaffna.

Shanthakumary, M.C.M.A (2019a,). Career orientation and work life outcomes: does gender make a difference, VISTAS Journal of Humanities and Social Sciences, Open University of Sri Lanka,12(1).

Shanthakumary, M.C.M.A (2019b). Protean career orientation and work life outcomes among graduate employees in Jaffna district, Unpublished $\mathrm{PhD}$ thesis. 